\title{
Studies on Hexokinase
}

\section{THE HEXOKINASE ACTIVITY OF RAT-BRAIN EXTRACTS}

\author{
By H. WEIL-MALHERBE AND A. D. BONE \\ Research Department, Runwell Hospital, Wickford, Essex
}

(Received 13 November 1950)

\begin{abstract}
This and the two following papers are part of an investigation which was originally undertaken to study the possibility of using the hexokinase reaction for the assay of hormonal changes in human blood. For this purpose it seemed inadvisable to use purified hexokinase preparations, since the interaction with hormones might conceivably depend on the association of the enzyme with other tissue constituents. Preliminary experiments had shown that aqueous extracts of rat brain possessed a hexokinase activity which was higher, more stable and more reproducible than similar extracts of rat muscle. Moreover, these extracts were practically free of carbohydrate and of codehydrogenases and their apyrase activity was low. Undesirable side reactions were therefore less likely to occur. For these reasons most experiments were performed with an aqueous extract of rat brain as a source of hexokinase. In this paper the properties of the enzyme system used, together with some new observations on brain hexokinase, will be described.
\end{abstract}

\section{METHODS AND MATERIALS}

\section{Abbreviations}

ATP $=$ adenosinetriphosphate; $\quad \mathrm{ADP}=$ adenosinediphos . phate; $P_{7 \text { min. }}=P$ of acid-hydrolysable phosphate groups of ATP and ADP; terminal $\mathbf{P}=$ terminal (myosin-labile) $\mathbf{P}$ of ATP; HMP = hexosemonophosphate; HDP = hexosediphosphate.

\section{Preparation of brain extracts}

A rat brain was homogenized for $3 \mathrm{~min}$. in a small glass homogenizer of close fit (Potter \& Elvehjem, 1936) with a total volume of $7 \mathrm{ml}$. glass-distilled water, added in portions, at $0^{\circ}$. After centrifuging for $5 \mathrm{~min}$. in an angle centrifuge at $3500 \mathrm{rev} . / \mathrm{min}$. the clear supernatant was taken off with a rubber-teat pipette, care being taken not to disturb the precipitate. The residue was suspended in $7 \mathrm{ml}$. water and again centrifuged. The combined extracts (approx. $11 \mathrm{ml}$.) contained about $6 \mathrm{mg}$. protein $/ \mathrm{ml}$. In the initial stages of the investigation the protein content of the extract was determined with Folin \& Ciocalteu's (1927) reagent and the volume adjusted to the desired protein concentration. The colour formation from brain extracts with the phenol reagent had previously been calibrated by simultaneous Kjeldahl estimations. Since the protein content of the brain extracts was found to vary little, this estimation was later omitted. Extracts prepared in this way were found to retain their hexokinase activity for 2-3 days at $0^{\circ}$.

\section{Composition of test solution}

In all experiments inorganic constituents were added to give the following concentrations (M): $\mathrm{NaHCO}_{3}, 0.02$; $\mathrm{MgCl}_{2}, 0.0067 ; \mathrm{NaF}, 0.0238$. The concentrations of brain extract, phosphate acceptor and phosphate donor were varied to suit the requirements of the experiment, but, unless otherwise stated, the standard concentrations were: brain extract, $0.2 \mathrm{ml}$. (approx. $1.2 \mathrm{mg}$. protein) $/ 3 \mathrm{ml}$.; glucose, $1.85 \mathrm{~mm}$; ATP, $3.33 \mathrm{~mm}$.

The usual volume of the test solution was $3 \mathrm{ml}$., but for some experiments it was increased to 6 or $10 \mathrm{ml}$.

Experiments were carried out at $30^{\circ}$ in an atmosphere of nitrogen containing $5 \%$ (by vol.) $\mathrm{CO}_{2}$.

\section{Measurement of reaction rates}

Manometric experiments. These were carried out in Warburg manometers. The reaction was started by tipping in the phosphate acceptor (glucose or HMP) from the side bulb; any pressure changes due to the reaction of ATP with preformed phosphate acceptors in the brain extract were thus avoided. With the small amounts of protein used, retention was found to be too small to be measured with accuracy. It was therefore neglected. Likewise, the 'esterification correction' (Meyerhof \& Kiessling, 1933) was negligible since the $K_{2}^{\prime}$ values of the disappearing phosphate esters did not significantly differ from those of the newly formed esters.

Chemical estimations. The measurement of reaction rates by chemical methods involved the analysis of an initial and subsequent samples. The reaction was started by adding the brain extract as last component. The initial sample was withdrawn immediately afterwards with a pipette and delivered into a solution of the appropriate deproteinizing agent.

\section{Analytical procedures}

Glucose. Glucose was estimated in $0.5-1.0 \mathrm{ml}$. samples by the method of Nelson (1944) after $\mathrm{Ba}(\mathrm{OH})_{2}-\mathrm{ZnSO}_{4}$ precipitation. All estimations were carried out in duplicate.

Phosphate fractions. Inorganic phosphate was determined by the method of Fiske \& Subbarow (1925) or, in later experiments, by a modification of the method of Martin \& Doty (1949; see Weil-Malherbe \& Green, 1951). The acidlabile phosphate groups of ATP and ADP were determined after hydrolysis in $\mathrm{N}-\mathrm{HCl}$ at $100^{\circ}$ for $7 \mathrm{~min}$. and corrected for the phosphate fraction hydrolysed between 7 and $30 \mathrm{~min}$. under the same conditions (Lohmann, 1928). Owing to the high yield of hexosediphosphate in these experiments serious errors were incurred if this correction was omitted.

ATP was determined from the phosphate hydrolysed by purified (four times precipitated) myosin; this was carried out as previously described (Weil-Malherbe, 1950) and 
ADP was calculated by the difference: $\left(P_{7 \text { min. }}\right)-2$ (myosinlabile $\mathrm{P}$ ).

For the simultaneous estimation of inorganic, acid-labile and myosin-labile $P, 4 \mathrm{ml}$. of test solution were added to $16 \mathrm{ml} .10 \%(w / v)$ trichloroacetic acid. The filtrate was measured and $1 \mathrm{ml}$. $\mathrm{N}-\mathrm{HCl}$ was added. The solution was extracted four times with $10 \mathrm{ml}$. portions of peroxide-free redistilled ether to remove excess trichloroacetic acid. Ether was removed in vacuo from the warmed solution which was then neutralized and made up to $20 \mathrm{ml}$. Inorganic $P$ was determined in a $4 \mathrm{ml}$. sample and acid-labile $P$ in two $1 \mathrm{ml}$. samples hydrolysed for 7 and $30 \mathrm{~min}$. respectively. Two samples of $6 \mathrm{ml}$. were used for the estimation of myosinlabile P. Care was taken to avoid an excess of myosin, as this might have resulted in a partial hydrolysis of the second phosphate group of ATP. The correct amount of myosin was found in preliminary experiments with ATP solutions of known concentration.

Hexosediphosphate. HDP was determined by the estimation of alkali-labile phosphate after incubation with aldolase in presence of KCN (Meyerhof, Ohlmeyer \& Möhle, 1938; Meyerhof \& Junowicz-Kocholaty, 1942). Crystalline aldolase was prepared from rabbit muscle by the method of Taylor, Green \& Cori (1948). The crystalline enzyme was dried in vacuo and $3 \mathrm{mg}$. of the powder, which contained some $\left(\mathrm{NH}_{4}\right)_{2} \mathrm{SO}_{4}$, were dissolved and added to a neutralized trichloroacetic acid filtrate. A calibration curve was determined with a solution of pure HDP.

The method estimates the sum of HDP and triosephosphates. All analytical results referring to ' $H D P$ ' represent in reality the sum of these compounds.

Ammonia. $\mathrm{NH}_{8}$ was distilled in the apparatus of Parnas \& Heller (1924) and determined by nesslerization.

\section{Chemical preparations}

$A T P$ was prepared from rabbit muscle by the method of Dounce, Rothstein, Beyer, Meier \& Freer (1948). A number of consecutive specimens showed a satisfactory ratio of total organic to acid-labile $\mathrm{P}$, though the figures were higher than those calculated for $\mathrm{Ba}_{2}\left(\mathrm{C}_{10} \mathrm{H}_{12} \mathrm{O}_{13} \mathrm{~N}_{5} \mathrm{P}_{3}\right) .4 \mathrm{H}_{2} \mathrm{O}(\mathrm{P}, 10.92$; $\mathrm{P}_{\mathbf{7} \text { min., }} \mathbf{7 \cdot 3} \%$ ), possibly due to the presence of some acid $\mathrm{Ba}$ salt. A specimen analysis was as follows: total organic $P$, $12.60 ; P_{7 \text { min., }} .36 \%$. The myosin-labile $P$. usually amounted to $29-33 \%$ of the total organic $P$.

$A D P$. After several unsatisfactory attempts with myosin a pure specimen of ADP was prepared with purified yeast hexokinase by incubating $30 \mathrm{mg}$. of enzyme-protein with $750 \mathrm{mg}$. glucose and $11.4 \mathrm{ml} .0 \cdot 1 \mathrm{M}$-ATP in bicarbonate- $\mathrm{CO}_{2}$ buffer ( $\mathrm{pH} \mathrm{7.4)}$ for $30 \mathrm{~min}$. at $30^{\circ}$. The volume of the solution, which also contained $\mathrm{Mg}^{++}$in the usual concentration, was $150 \mathrm{ml}$. The ADP formed was purified through its mercuric and $\mathrm{Ba}$ salts in the usual way. Yield: $390 \mathrm{mg}$. Ba salt (total organic $\mathrm{P}, 8.7 \% ; \mathrm{P}_{7 \text { min. }}, 4.49 \%$ ).

The yeast hexokinase was obtained by the procedure of Berger, Slein, Colowick \& Cori (1946) and corresponded to their fraction $3 a$. The bulk of the preparation which was not used for the preparation of ADP was dried after precipitation with $\left(\mathrm{NH}_{4}\right)_{2} \mathrm{SO}_{4}$ (0.7 saturation). The enzyme preparation obtained on solution and dialysis was highly active.

Hexosemonophosphates. A specimen of the neutral Ba salt of Robison ester mixture was given by Dr M. G. Macfarlane. Organic P: $8 \cdot 08 \%$ (on air-dried material).

A specimen of greater purity was isolated after the experiment in which ADP was prepared by adding an equal volume of ethanol to the supernatant from the first $\mathrm{Ba}$ precipitation. The air-dried $\mathrm{Ba}$ salt (340 mg.) contained $7.08 \%$ organic P. Estimation of fructose (Roe, 1934) and aldose titration (Macleod \& Robison, 1929) revealed a content of $45 \%$ ketose and $55 \%$ aldose.

Fructose-6-phosphate was prepared from HDP as the Ba salt according to Neuberg, Lustig \& Rothenberg (1943). Organic P: $6 \cdot 43 \%$ (on air-dried material).

Glucose-6-phosphate was synthesized by the method of Lardy \& Fischer (1946). The Ca salt, dried in vacuo at $78^{\circ}$, contained $10.69 \%$ organic $P$.

Hexosediphosphate. The acid $\mathrm{Ba}$ salt was prepared from a commercial sample (Schwarz Laboratories, New York) according to Neuberg et al. (1943). It contained $12.80 \%$ organic $\mathbf{P}$.

All Ba salts were converted to the $K$ salts for use. Ca glucose-6-phosphate was converted to the $\mathrm{Na}$ salt by passage through a column of Zeo-Karb 215 (Permutit Company Ltd., London), pretreated with $\mathrm{Na}^{+}$.

Adenylic acid was prepared by alkaline hydrolysis of ATP (Lohmann, 1932). It contained $\mathbf{9 \cdot 3} \%$ organic P.

Cozymase, of purity 50-60\%, was prepared by the method of LePage (1947).

Insulin hydrochloride of low $\mathrm{Zn}$ content was obtained from British Drug Houses Ltd. and had: Zn, 0.035 \%; activity, 20-21 units/mg.

\section{Experimental error}

A measure of the experimental error was obtained by the statistical analysis of fifty pairs of duplicate experiments in which hexokinase activity was determined by the rate of glucose disappearance. A standard deviation of 6.55\% was found. Deviations $\geqslant \pm 17 \%$ from the control experiment may therefore be regarded as significant $(P \leqslant 0 \cdot 01)$.

\section{RESULTS}

\section{The effect of substrate concentration}

Glucose. The affinity between brain hexokinase and glucose is so great that the initial reaction rate (observed manometrically) is independent of the concentration of glucose above values of $0.1 \mathrm{~mm}$. To obtain reliable results with smaller

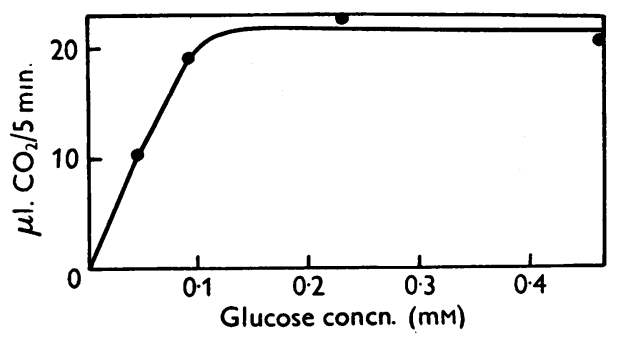

Fig. 1. Effect of glucose concentration on the initial rate of the hexokinase reaction. Manometric experiment: $0.1 \mathrm{ml}$. brain extract in $6 \mathrm{ml}$. Other components in standard concentration.

concentrations it was necessary to double the standard volume of solution per vessel and to reduce the standard concentration of brain extract to one-fourth. In this way the Michaelis constant, $K_{m}$, was estimated to be approximately $5 \times 10^{-5} \mathrm{M}$ (Fig. 1). This value is not very different from that of $1 \times 10^{-4} \mathrm{M}$ reported by Harpur \& Quastel (1949). 
Hexosemonophosphate. The Michaelis constant for the phosphorylation of hexosemonophosphate is appreciably greater than that for glucose. Values of $K_{m}$, obtained in several experiments, lay in the range 4-10 $\times 10^{-4} \mathrm{M}$ (Fig. 2) and are thus of an order similar to those obtained for fructose and D-glucosamine (Harpur \& Quastel, 1949).

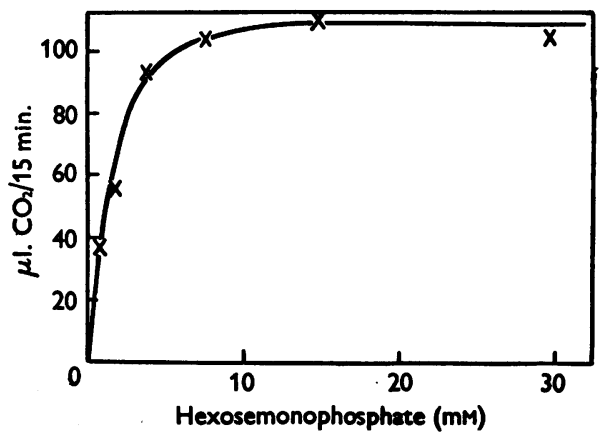

Fig. 2. Effect of hexosemonophosphate concentration on the initial activity of phosphohexokinase. ATP added: $20 \mu \mathrm{mol} . / 3 \mathrm{ml}$. Other components in standard concentration.

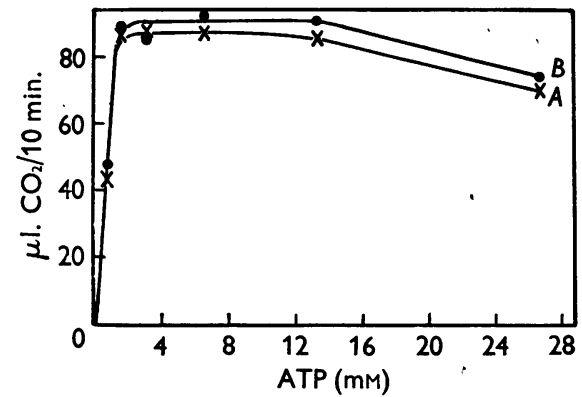

Fig. 3. Effect of ATP concentration on the initial rate of hexokinase and phosphohexokinase reactions. HMP added: $11 \cdot 1 \mu \mathrm{mol} . / 3 \mathrm{ml}$. Other components in standard concentration. Curve $A$, with glucose as substrate. Curve $B$, with HMP as substrate.

$A T P$. The maximum initial velocity of phosphorylation was reached with a concentration of 1.5-2 mM-ATP, with either glucose or hexosemonophosphate as phosphate acceptor (Fig. 3). This, however, was true only for the first 5-10 min. and, as the reaction progressed, the rate was maintained better if ATP was present in excess. Under the standard conditions of enzyme and glucose concentration, a concentration of $3.33 \mathrm{mM}$-ATP maintained the reaction at about its maximum rate for at least $20 \mathrm{~min}$.

\section{Reaction products}

Manometric experiments. The manometric measurement of hexokinase activity in brain extracts is complicated by some side reactions, but the necessary corrections are small. The activity of apyrase was identical in the presence and in the absence of phosphate acceptors, as shown by the increase of inorganic phosphate (Table 1). A correction for the pressure changes due to apyrase activity can therefore be based on a control experiment without phosphate acceptors.

After the completion of the phosphorylation reaction a small negative pressure was usually observed. Similar pressure changes were observed when ADP or adenylic acid was added to brain extract. It was therefore attributed to the activity of adenylic deaminase.

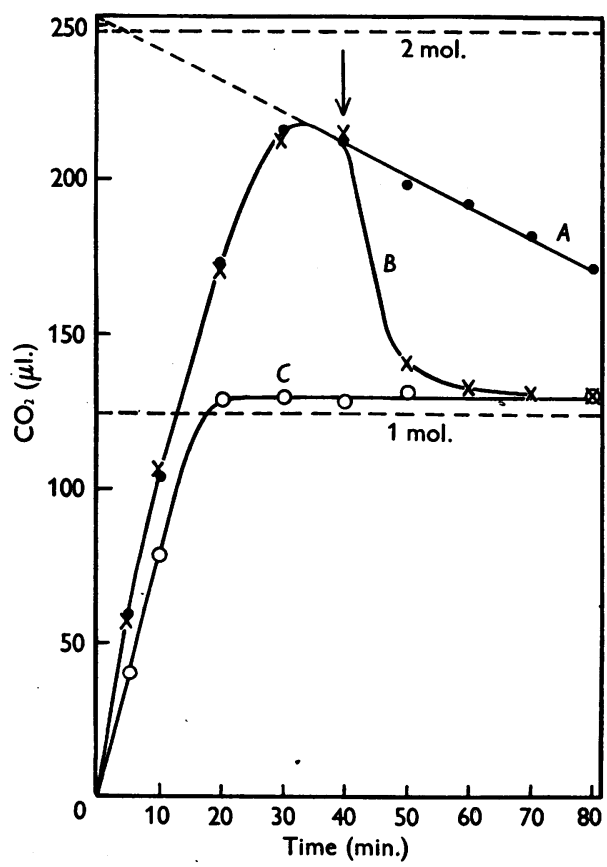

Fig. 4. Acid formation during hexokinase reaction. Brain extract, $0.4 \mathrm{ml}$; ATP, $20 \mu \mathrm{mol}$; glucose, $5.55 \mu \mathrm{mol}$. in $3 \mathrm{ml}$. Curve $\mathrm{A}, \mathrm{CO}_{2}$ evolution in presence of brain extract only. Curve $B$, addition of $1 \mathrm{mg}$. adenylic deaminase (fraction 3P, Weil-Malherbe \& Bone, $1951 b$ ) after $40 \mathrm{~min}$. Curve $C$, addition of $1 \mathrm{mg}$. adenylic deaminase at beginning of experiment.

The final yield of acid formation could be corrected for the activity of adenylic deaminase either by extrapolating the descending part of the curve back to zero time (see Figs. 4

Table 1. End products of hexokinase and phosphohexokinase reactions

(Brain extract 0.3 ml.; ATP, $20 \mu \mathrm{mol}$. in $3 \mathrm{ml}$. Duration of experiment, $50 \mathrm{~min}$.)

\begin{tabular}{|c|c|c|c|c|c|}
\hline \multirow{2}{*}{$\begin{array}{l}\text { Substrate added } \\
\qquad(\mu \mathrm{mol} .)\end{array}$} & \multicolumn{5}{|c|}{ Reaction products ( $\mu \mathrm{mol})}$. \\
\hline & $\mathrm{CO}_{2}$ & Inorganic $\mathbf{P}$ & $\mathrm{NH}_{3}$ & HDP & $\mathrm{CO}_{2}{ }^{*}+\mathrm{NH}_{3}{ }^{*}$ \\
\hline No addition & 0.9 & $1 \cdot 3$ & 0.7 & 0. & $\overline{110}$ \\
\hline Glucose $(5 \cdot 55)$ & 10.0 & $1 \cdot 1$ & $2 \cdot 6$ & $5 \cdot 6$ & $11 \cdot 0$ \\
\hline HMP (11.1) & $9 \cdot 8$ & 1.2 & $2 \cdot 7$ & $9 \cdot 3$ & 10.9 \\
\hline
\end{tabular}

* Corrected for control value without substrate. 
and 7) or by the estimation of $\mathrm{NH}_{3}$ formation, corrected for the $\mathrm{NH}_{3}$ formation in a control experiment without phosphate acceptors (Table 1). With either method the result usually corresponded closely to the theoretical yield of $2 \mathrm{~mol}$. acid in the case of glucose and of $1 \mathrm{~mol}$. acid in the case of hexosemonophosphate.

Addition of a muscle fraction with high adenylic deaminase activity (fraction $3 P$, Weil-Malherbe \& Bone, 1951 b) after completion of the phosphorylation reaction resulted in an immediate rapid gas absorption. When the reaction was terminated the final acid formation amounted to $1 \mathrm{~mol} . / \mathrm{mol}$. glucose (Fig. 4, curve $B$ ) in agreement with the reaction:

$$
\text { Glucose + ATP } \rightarrow \mathrm{HDP}+\mathrm{NH}_{3}+\text { inosinic acid. }
$$

The same end value was reached when the muscle fraction was present from the beginning of the reaction (Fig. 4, curve $C$ ).

The $\mathrm{CO}_{2}$ evolution was usually linear until the reaction was almost completed (Fig. 4, curve $A$ ), but an initial lag period, lasting for 10-20 min., was repeatedly observed, so that the resulting curve was slightly sigmoid in shape (Fig. 7, curve $A$ ).

If the reaction was stopped after $30-50 \%$ of the glucose had disappeared, the ratio of acid formation to glucose disappearance was often significantly smaller than 2, probably indicating an intermediate accumulation of hexosemonophosphate. This decrease of the $\mathrm{CO}_{\mathrm{a}} /$ glucose ratio was the more marked the greater the dilution of the brain extract (Table 2). to a similar end value (Table 3) showing that isomerase activity was not a limiting factor in the brain extracts.

Formation of hexosediphosphate. Under the conditions of our experiments added hexosediphosphate was quantitatively recovered after incubation with brain extract. The rapid destruction of coenzymer by the powerful nucleotidase of brain (McIlwain \& Rodnight, 1949) effectively blocked glycolysis at the triosephosphate stage. The use of iodoacetate, advocated by Wiebelhaus \& Lardy (1949), is therefore unnecessary.

The measurement of hexosediphosphate formation after the completion of the phosphorylation reaction indicated a quantitative conversion of both glucose and hexosemonophosphate to hexosediphosphate (Table 1), thus confirming the manometric experiments. On the other hand, lower yields were sometimes found when the reaction was stopped before it had gone to completion, especially when dilute brain extracts were employed (Table 2).

Phosphate utilization. The increase of inorganic phosphate in brain extracts was practically nil in the absence of ATP, even if hexosemono- or hexosediphosphate were added. In the presence of ATP, therefore, formation of inorganic phosphate may be attributed to apyrase activity. (The term apyrase is used to indicate the enzymic breakdown of ATP to adenylio acid and inorganic phosphate, even though it is possible that 'apyrase' activity is due to the combined action of ATPase and myokinase.) Accordingly the utilization of phosphate in the hexokinase reaction is obtained

Table 2: Effect of enzyme concentration on ratios of carbon dioxide evolved and hexosediphosphate formed to glucose disappearing

\begin{tabular}{|c|c|c|c|c|c|c|c|}
\hline \multirow{3}{*}{$\begin{array}{c}\text { Brain } \\
\text { extract } \\
\text { protein } \\
\text { (mg./3 ml.) }\end{array}$} & \multicolumn{7}{|c|}{ (ATP concn. 6.67 mM.) } \\
\hline & \multicolumn{5}{|c|}{$\mu \mathrm{mol}$. } & \multirow{2}{*}{$\begin{array}{c}-\Delta \mathrm{CO}_{2} / \\
\Delta \text { glucose }\end{array}$} & \multirow{2}{*}{$\begin{array}{c}-\Delta \mathrm{HDP} / \\
\Delta \text { glucose }\end{array}$} \\
\hline & Glucose added & $\Delta$ Glucose & $\begin{array}{l}\triangle \mathrm{CO}_{2} \\
\mathrm{xp.} \text {. }\end{array}$ & $\begin{array}{l}\Delta \text { Inorganic } P \\
\text { ation } 20 \mathrm{~min} .\end{array}$ & $\triangle \mathrm{HDP}$ & & \\
\hline $\begin{array}{l}0 \cdot 4 \\
1 \cdot 2 \\
3 \cdot 6\end{array}$ & $\begin{array}{l}2 \cdot 77 \\
5 \cdot 55 \\
11 \cdot 1\end{array}$ & $\begin{array}{l}-0.83 \\
-2 \cdot 2 \\
-6.4\end{array}$ & $\begin{array}{r}1.0 \\
2.9 \\
10.8\end{array}$ & $\begin{array}{l}0.12 \\
0.35 \\
0.50\end{array}$ & $\begin{array}{l}0 \\
0 \cdot 8 \\
4 \cdot 2\end{array}$ & $\begin{array}{l}1 \cdot 20 \\
1 \cdot 32 \\
1 \cdot 69\end{array}$ & $\begin{array}{l}\overline{0.36} \\
0.66\end{array}$ \\
\hline \multicolumn{8}{|c|}{ Exp. 2. Changes in first $20 \mathrm{~min}$. } \\
\hline $\begin{array}{l}1 \cdot 2 \\
3 \cdot 6\end{array}$ & $\begin{array}{l}5 \cdot 55 \\
11 \cdot 1\end{array}$ & $\begin{array}{l}-1 \cdot 53 \\
-4 \cdot 88\end{array}$ & $\begin{array}{l}1 \cdot 62 \\
8 \cdot 15\end{array}$ & $\begin{array}{l}0.77 \\
0.97\end{array}$ & $\begin{array}{l}0 \cdot 63 \\
4 \cdot 9\end{array}$ & $\begin{array}{l}1.06 \\
1.67\end{array}$ & $\begin{array}{l}0.41 \\
1.0\end{array}$ \\
\hline \multicolumn{8}{|c|}{ After completion of reaction (80 $\mathrm{min})}$. \\
\hline $\begin{array}{l}1 \cdot 2 \\
3 \cdot 6\end{array}$ & $\begin{array}{l}5 \cdot 55 \\
11 \cdot 1\end{array}$ & $\begin{array}{l}-5 \cdot 55 \\
-11 \cdot 1\end{array}$ & $\begin{array}{r}9 \cdot 0 \\
18 \cdot 5\end{array}$ & $\begin{array}{l}1 \cdot 68 \\
\mathbf{3} \cdot 80\end{array}$ & $\begin{array}{r}4 \cdot 8 \\
11 \cdot 0\end{array}$ & $\begin{array}{l}1.62 \\
1.67\end{array}$ & $\begin{array}{l}0.87 \\
0.99\end{array}$ \\
\hline
\end{tabular}
Table 3. Acid formation during phosphorylation
of hexosemonophosphate

(Brain extract, $0.3 \mathrm{ml}$; ATP, $20 \mu \mathrm{mol}$. in $3 \mathrm{ml}$.)

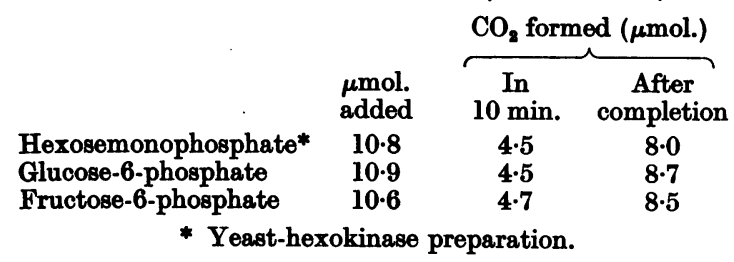

Equivalent amounts of hexosemonophosphate (yeast hexokinase preparation), fructose-6-phosphate and glucose6-phosphate caused acid production at a similar rate and up from (decrease of $P_{7 \text { tuln. }}$ fraction) - (increase of inorganic $P$ ) and the utilization of ATP from (decrease of terminal $P$ fraction) -0.5 (increase of inorganic $P$ ). It must be emphasized again that it is essential to correct the phosphate hydrolysed after $7 \mathrm{~min}$. by the increment of phosphate hydrolysis occurring between 7 and $30 \mathrm{~min}$. as described.

The ratio of $P$ utilized to glucose disappearance was close to the theoretical value of 2 in most experiments (Tables 4 and 5). It was of interest to know what proportion of the phosphate utilized originated from the terminal and from the intermediate phosphate group of ATP respectively. The calculation of the ADP formed during the reaction showed that in some experiments practically no ADP accumulated, but in others significant amounts were formed (Table 4). The brain extracts thus contain myokinase, whose activity is, however, not always sufficient to keep pace with the forma- 
Table 4. The phosphate balance of the hexokinase reaction in brain extracts

(Brain extract, 0.9 ml.; glucose, 16.67 $\mu \mathrm{mol}$.; ATP, $40 \mu \mathrm{mol}$. in $10 \mathrm{ml}$. Duration of experiment, $20 \mathrm{~min}$.)

\begin{tabular}{|c|c|c|c|c|c|c|c|c|}
\hline \multirow[b]{2}{*}{$\begin{array}{l}\text { Exp. } \\
\text { no. }\end{array}$} & \multicolumn{7}{|c|}{$\mu \mathrm{mol}$} & \multirow[b]{2}{*}{$\begin{array}{l}\text { P utilized } \\
\Delta \text { glucose }\end{array}$} \\
\hline & $\underset{\text { Glucose }}{\Delta}$ & $\underset{\text { Inorganic } P}{\Delta}$ & $\begin{array}{c}\Delta \\
\mathbf{P}_{7 \min } .\end{array}$ & $\underset{\text { utilized }^{*}}{\mathbf{P}}$ & $\Delta \mathrm{ATP}$ & $\underset{\text { utilized* }}{\text { ATP }}$ & $\Delta \mathrm{ADP}$ & \\
\hline $\begin{array}{l}1 \\
2 \\
3\end{array}$ & $\begin{array}{l}-7 \cdot 2 \\
-9 \cdot 9 \\
-8 \cdot 4\end{array}$ & $\begin{array}{l}1.08 \\
3 \cdot 2 \\
0.7\end{array}$ & $\begin{array}{l}-15.6 \\
-21.8 \\
-18.3\end{array}$ & $\begin{array}{l}14 \cdot 5 \\
18 \cdot 6 \\
17 \cdot 6\end{array}$ & $\begin{array}{l}-8.5 \\
-11.0 \\
-11.8\end{array}$ & $\begin{array}{r}8.0 \\
9 \cdot 4 \\
11 \cdot 4\end{array}$ & $\begin{array}{l}1 \cdot 5 \\
0 \cdot 2 \\
5 \cdot 3\end{array}$ & $\begin{array}{l}2.01 \\
1.88 \\
2.09\end{array}$ \\
\hline
\end{tabular}

Table 5. Activity of ATP and ADP as phosphate donors in the hexokinase reaction

(Brain extract, $0.2 \mathrm{ml}$.; glucose, 5.55 $\mu \mathrm{mol}$.; ATP, $10 \mu \mathrm{mol}$. or ADP, $20 \mu \mathrm{mol}$. in $3 \mathrm{ml}$. Duration of experiment, $20 \mathrm{~min}$.)

\begin{tabular}{|c|c|c|c|c|c|c|}
\hline \multirow{2}{*}{$\begin{array}{c}\text { Exp. } \\
\text { no. }\end{array}$} & \multirow{2}{*}{$\begin{array}{l}\text { Phosphate } \\
\text { donor }\end{array}$} & \multicolumn{5}{|c|}{$\mu \mathrm{mol}$} \\
\hline & & $\Delta$ Glucose & $\Delta$ Inorganic $\mathrm{P}$ & $\Delta P_{7_{\text {min }} .}$ & P utilized & $\mathrm{NH}_{3}{ }^{*}$ \\
\hline 1 & $\begin{array}{l}\text { ATP } \\
\text { ADP }\end{array}$ & $\begin{array}{l}-2 \cdot 7 \\
-2 \cdot 0\end{array}$ & $\begin{array}{l}1.6 \\
1.0\end{array}$ & $\begin{array}{l}-7 \cdot 0 \\
-4 \cdot 6\end{array}$ & $\begin{array}{l}5 \cdot 4 \\
3 \cdot 6\end{array}$ & $\begin{array}{l}1.06 \\
2 \cdot 12\end{array}$ \\
\hline 2 & ATP & $-3 \cdot 3$ & - & - & - & - \\
\hline & ADP & $-2 \cdot 0$ & - & - & - & - \\
\hline 3 & $\begin{array}{l}\text { ATP } \\
\text { ADP }\end{array}$ & $\begin{array}{l}-3 \cdot 8 \\
-2 \cdot 7\end{array}$ & E & - & - & E \\
\hline & & & * In 60 min. & & & \\
\hline
\end{tabular}

tion of ADP by hexokinase. If ATP is replaced by ADP as phosphate donor the rate of the reaction is reduced by about $30 \%$ (Table 5). This may be due to an inhibitory effect of ADP or to the fact that, in absence of ATP, the reaction rate is limited by the activity of myokinase. It is, however, unlikely that myokinase activity was limiting in presence of ATP, as the latter was always added in considerable excess. Moreover, at the end of the experiment, about $70 \%$ of the amount initially added could be recovered (Table 4).

Ammonia formation. In absence of phosphate acceptors about 1 mol. of $\mathrm{NH}_{3}$ was formed for 2 mol. of inorganic $\mathrm{P}$. $\mathrm{NH}_{\mathbf{3}}$ formation in presence of phosphate acceptors was only slightly higher (Tables 1 and 5), indicating a fairly weak activity of adenylic deaminase. Similar amounts of $\mathrm{NH}_{3}$ were formed from adenylic acid and from ADP (Table 6); myokinase activity was therefore not a limiting factor for ammonia formation.

\section{Table 6. Ammonia formation from $A D P$ and adenylic acid in brain extract}

(Brain extract, 0.2 ml.; ADP or adenylic acid, $10 \mu \mathrm{mol}$. in $3 \mathrm{ml}$. Duration of experiment, $80 \mathrm{~min}$.)

$\begin{array}{lc} & \Delta \mathrm{NH}_{\mathbf{3}} \\ & \left(\boldsymbol{\mu \mathrm { mol } _ { . } )}\right) \\ \text { ADP } & \mathbf{2 \cdot 7} \\ \text { Adenylic acid } & \mathbf{2 \cdot 9}\end{array}$

The activities of apyrase, myokinase and adenylic deaminase were somewhat variable in different extracts. Moreover, they seemed to vary in parallel. According to Meyerhof \& Geliazkowa (1947) brain apyrase is largely bound to insoluble tissue particles. If the same is true for myokinase and adenylic deaminase the observed variations may be explained by the varying efficiency of comminution, centrifugation and the separation of the supernatant. Though the procedure was standardized as far as possible, a complete control of these factors was apparently not achieved.

\section{Inhibition by reaction products}

According to Colowick \& Kalckar (1943) yeast hexokinase is not inhibited by either ADP, adenylic acid or hexosemonophosphate, while myokinase is inhibited by adenylic acid. We have fully confirmed these observations. But in contrast to yeast hexokinase the hexokinase of brain extracts is strongly inhibited by hexosemonophosphate in low concentrations. In spite of the presence of isomerase it was found in experiments of short duration that glucose-6-phosphate is more inhibitory than fructose-6-phosphate and that the inhibitory effect of the natural equilibrium mixture is about half-way between those of the pure components (Table 7),

Table 7. Effects of hexosemonophosphates and adenylic acid on the hexokinase activity of brain extracts

(Brain extract, glucose and ATP in standard concn.; duration of experiment, $20 \mathrm{~min}$.)

\begin{tabular}{lccc}
\multicolumn{1}{c}{ Addition } & $\begin{array}{c}\text { Concn. } \\
(\mathrm{mM})\end{array}$ & $\begin{array}{c}\text { Decrease in } \\
\text { glucose } \\
(\mathrm{mg} .)\end{array}$ & $\begin{array}{c}\text { Inhibition } \\
(\%)\end{array}$ \\
None & - & 0.473 & - \\
Hexosemonophosphate* & 0.55 & 0.398 & 16 \\
& 1.83 & 0.263 & 44.5 \\
Fructose-6-phosphate & $\mathbf{0 . 5 5}$ & 0.430 & 9 \\
Glucose-6-phosphate & 1.83 & 0.360 & 24 \\
& 0.55 & 0.347 & 26.5 \\
None & 1.83 & 0.140 & 72 \\
Adenylic acid & - & 0.180 & - \\
& 3.33 & 0.203 & 0
\end{tabular}

* Yeast-hexokinase preparation.

suggesting that the effect is due solely to glucose-6-phosphate. As regards the different response of brain and yeast hexokinase, it may be recalled that adrenochrome inhibits the former but not the latter (Meyerhof \& Randall, 1948). 


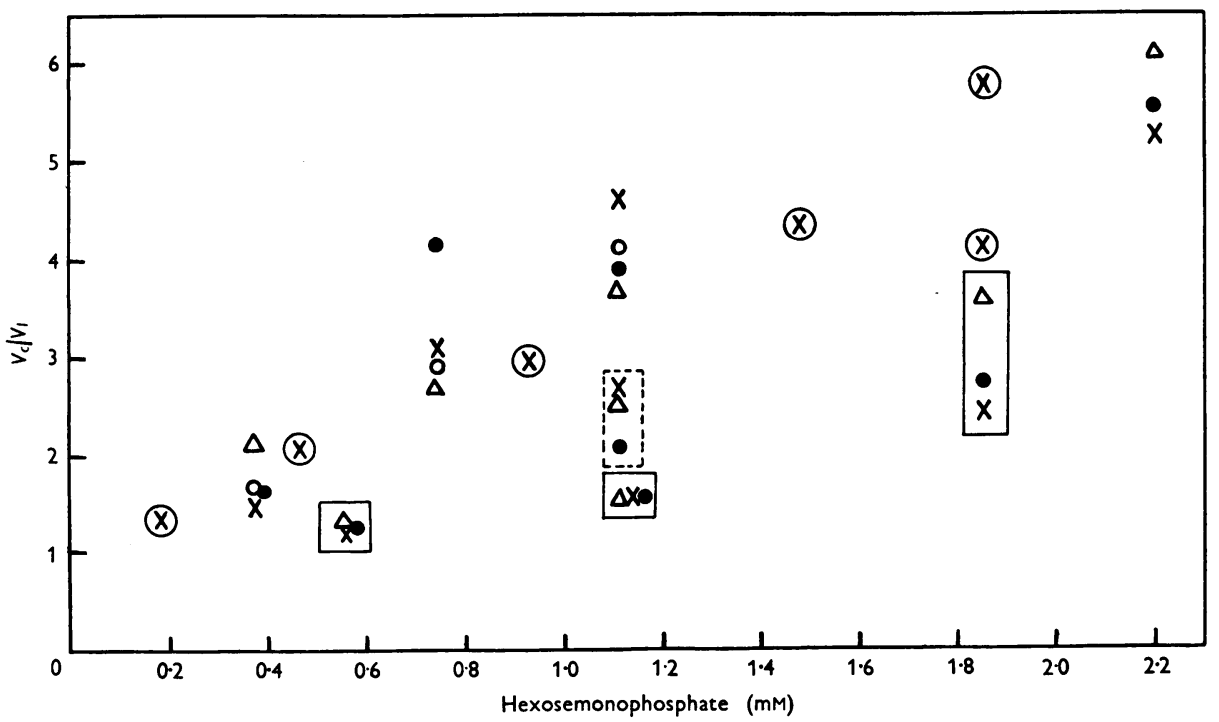

Fig. 5. Effect of glucose concentration on the inhibition of brain-hexokinase activity by increasing concentrations of hexosemonophosphates. Brain extract, $0.2 \mathrm{ml}$; ATP, $10 \mu \mathrm{mol}$. in $3 \mathrm{ml}$. The figure includes the results of several experiments. Exp. 1 (unenclosed symbols): hexosemonophosphate. Exp. 2 (symbols in circles): hexosemonophosphate. Exps. 3-6 (symbols in rectangles): fructose-6-phosphate. $V_{c}=$ reaction rate of control, $V_{I}=$ reaction rate in presence of inhibitor. $0,0.370 \mathrm{~mm}$-glucose; $\Delta, 0.925 \mathrm{~mm}$-glucose; $\times, 1.85 \mathrm{~mm}$-glucose;, $3.70 \mathrm{~mm}$-glucose.

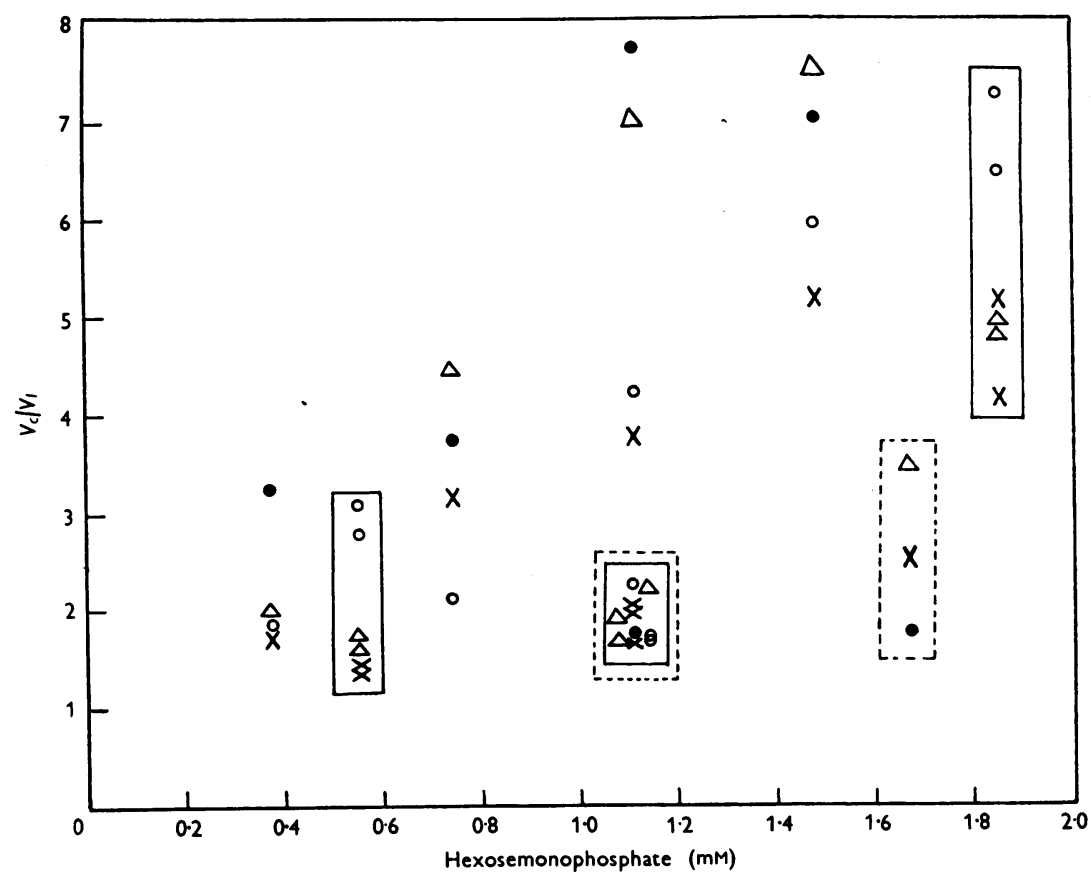

Fig. 6. Effect of ATP concentration on the inhibition of brain-hexokinase activity by increasing concentrations of hexosemonophosphates. Brain extract, 0.2 ml.; glucose, $5 \cdot 55 \mu \mathrm{mol}$. in $3 \mathrm{ml}$. Exp. 1 (unenclosed symbols): hexosemonophosphate. Exp. 2 (symbols in full-line rectangle): fructose-6-phosphate. Exp. 3 (symbols in dotted-line rectangle): fructose-6-phosphate. $V_{c}, V_{I}$ as in Fig. 5. O, 1.67 mM-ATP; $\triangle, 3.33$ mм-ATP; $\times, 6.67$ mM-ATP; $0,10.0$ mM-ATP. 
A graphical analysis according to the method of Ebersole, Guttentag \& Wilson (1944) showed that the inhibition is noncompetitive with respect to either glucose or ATP (Figs. 5 and 6). With concentrations of ATP $<2 \mathrm{~mm}$ an increase of inhibition was sometimes found compared with higher concentrations of ATP, but above this level the inhibitory effect did not consistently vary with ATP concentration. At the lower levels of ATP concentration the saturation of hexokinase and phosphohexokinase was presumably incomplete resulting in a slower rate of hexosemonophosphate disappearance.

There was no inhibition of hexokinase by adenylic acid (Table 7), or of hexokinase or phosphohexokinase by hexosediphosphate. The absence of an inhibitory effect of adenylic acid strengthens the conclusion that, under the conditions employed, the reaction rate is not limited by myokinase activity.

\section{Summation experiments}

When the phosphorylation of glucose, hexosemonophosphate and of both together was measured by the manometric method, the initial reaction rates were about equal (Fig. 7).

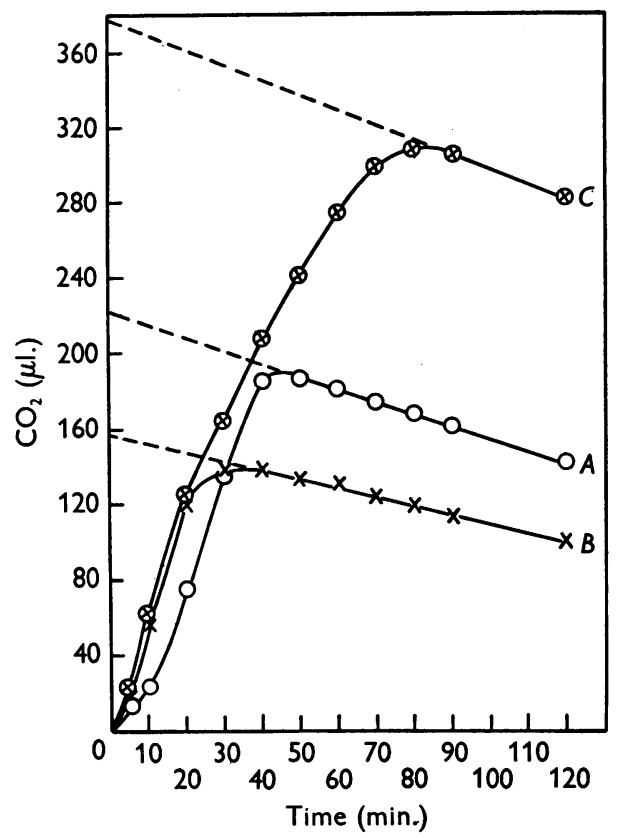

Fig. 7. Summation experiment, manometric. Brain extract, $0.3 \mathrm{ml}$.; ATP, $20 \mu \mathrm{mol}$. in $3 \mathrm{ml}$. Curve $A$, acid formation during phosphorylation of $5.5 \mu \mathrm{mol}$. glucose. Curve $B$, acid formation during phosphorylation of $\mathbf{7 \cdot 2} \mu \mathrm{mol}$. glucose-6-phosphate. Curve $C$, acid formation in presence of both substrates.

There was thus no summation. Two explanations are possible: either the two phosphorylation reactions are limited by the activity of a common factor or the phosphorylation of glucose is virtually suspended until most of the inhibitory glucose-6-phosphate has been removed. The only factor known to be common to both hexokinase and phosphohexokinase is ATP, which was present in sufficient excess to saturate both systems. That the second explanation is probably correct is indicated by the course of glucose disappearance as determined chemically in a parallel experiment; it shows that the reaction was strongly inhibited so long as hexosemonophosphate was present (Fig. 8).

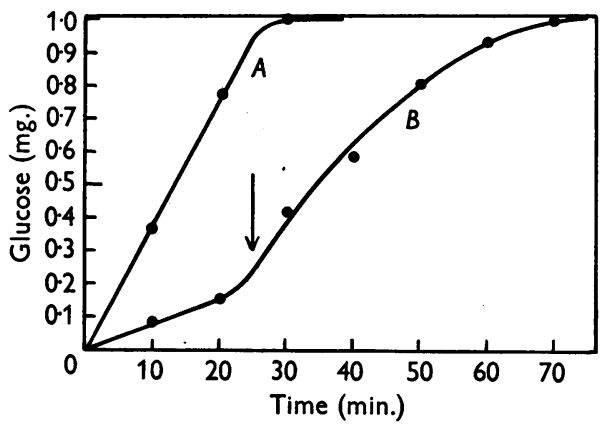

Fig. 8. Summation experiment; chemical estimation of glucose disappearance. Conditions as in experiment of Fig. 7. Curve $A$, glucose disappearance in absence of glucose-6-phosphate. Curve $B$, glucose disappearance in presence of $7 \cdot 2 \mu \mathrm{mol}$. glucose-6-phosphate. The arrow indicates the completion of glucose-6-phosphate phosphorylation in the simultaneous manometric experiment.

The phosphorylation of hexosemonophosphate in preference to glucose may seem in disagreement with the fact that the affinity of glucose for the phosphorylating enzyme is higher than that of hexosemonophosphate. In reality, no such contradiction exists, as the inhibition by hexosemonophosphate was found to be non-competitive and therefore independent of the relative affinities of the two substrates. Furthermore, while the inhibitory compound, glucose-6phosphate, reacts with hexokinase, the substrate of phosphorylation, fructose-6-phosphate, reacts with a different enzyme, phosphohexokinase.

\section{Activity of rat-brain hexokinase in presence of various substances}

In view of the activation of hexokinase by proteins from erythrocytes and muscle tissue (Weil-Malherbe \& Bone, $1951 a, b)$ it was necessary to investigate the specificity of the effect. A number of substances were therefore tested for their effect on hexokinase activity. Those selected were known to have a protective effect on enzymes in general, either by their colloidal nature, by their combination with heavy metals or by their reducing properties. The first group included glycogen, gum arabic and several proteins, such as casein, horse serum (dialysed against distilled water and inactivated at $56^{\circ}$ for $4 \mathrm{hr}$.), and ovalbumin, both before and after heat denaturation; the second group consisted of cyanide, pyrophosphate and the amino-acids histidine and glycine; and the third group of the thiol compounds cysteine and glutathione, and ascorbic acid. None of these substances caused any signficant activation.

In all experiments ATP was added in the form of the $\mathrm{K}$ salt. The concentration of $\mathrm{K}^{+}$was therefore $0.0132 \mathrm{M}$. Any further increase of the $K$ concentration, or complete replacement of $\mathrm{Na}$ by $\mathrm{K}$ was without effect on hexokinase activity. 
In addition, certain substances were tested, which were reported, or may be suspected, to have activating effects on hexokinase. But in our experiments no activation was observed with cozymase or reduced cozymase (Colowick \& Price, $1945 a$ ), both in presence and absence of nicotinamide, with guanine (Colowick \& Price, $1945 b$ ), with insulin, with acetylcholine or with various combinations of these compounds. In view of the negative results of these experiments, the actual figures are omitted.

\section{DISCUSSION}

The brain extracts used in these experiments were shown to convert glucose quantitatively to hexosediphosphate. In addition to hexokinase and phosphohexokinase they contain small and somewhat variable amounts of 'apyrase', myokinase and adenylic deaminase resulting in the formation of adenylic and inosinic acids from ATP and ADP. The myokinase activity is usually sufficiently great to ensure at least a partial utilization of the intermediate phosphate group of ATP, but, except perhaps with ADP as phosphate donor, the reaction rate was not limited by the activity of myokinase owing to the presence of a sufficient excess of ATP.

There are indications that in the initial phases of the reaction, and especially with more dilute extracts, some hexosemonophosphate accumulates. But this accumulation is unlikely to go far as it would soon cause inhibition of hexokinase activity and a preferential phosphorylation of hexosemonophosphate.

These results differ in some respects from those obtained by Meyerhof and his colleagues in similar experiments. Meyerhof \& Geliazkowa (1947) found apyrase activity to be greater in the absence than in the presence of phosphate acceptors, whereas we
(22 $\mu \mathrm{mol}$.) was present in excess (initial concentration of ATP 3-4 $\mu \mathrm{mol}$.). Meyerhof \& Geliazkowa also claim, on indirect evidence, that ADP was practically stable in their brain extracts owing to the absence of myokinase. Yet in later experiments (Meyerhof \& Wilson, 1948) it was shown that ADP was utilized as phosphate donor with the same efficiency as ATP. Finally, Meyerhof \& Randall (1948) assume that 'nothing but HMP is formed at first with an excess of glucose'. This conclusion was based on the observation of a ratio of $P$ utilization to glucose disappearance of 1 , but the figures for $P$ utilization were not corrected for the simultaneous hydrolysis of hexosediphosphate by subtracting the increment of phosphate hydrolysis occurring between 7 and $30 \mathrm{~min}$. from the $7 \mathrm{~min}$. hydrolysis. Relying on this statement we also at first omitted the correction and sometimes found ratios close to 1 . When the correction was applied, however, substantially higher ratios were obtained and we are therefore inclined to regard the earlier observations as fortuitous.

Since the inhibition of hexokinase by hexosemonophosphate is, on the whole, independent of the concentration of either glucose or ATP, it is of a non-competitive nature. According to current interpretations of the mechanism of enzyme action this means that hexosemonophosphate combines with the enzyme at a site different from those which react with either glucose or ATP, but which is nevertheless essential for the reaction. If we designate this site by the number 3 , and the sites reacting with ATP and glucose by 1 and 2, respectively, the mechanism of action of brain hexokinase may perhaps be envisaged as taking place in the following stages:

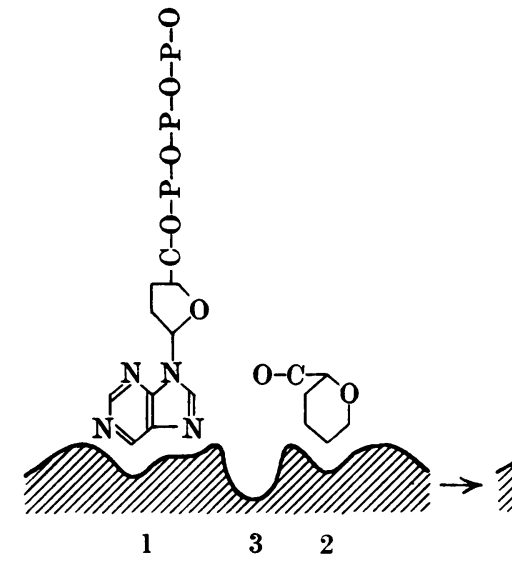

found it to be the same in both cases. The.difference is probably due to the fact that we used an excess of ATP (10-20 $\mu \mathrm{mol}$.) over glucose (5.5 $\mu \mathrm{mol}$.$) , while in$ Meyerhof \& Geliazkowa's experiments glucose

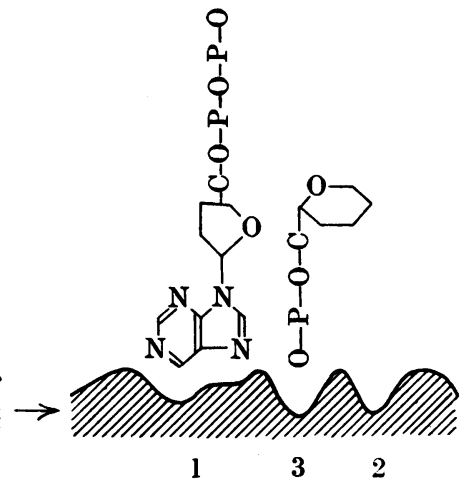

ATP is assumed to react with site 1 in such a way that its terminal phosphate group is free; similarly, glucose is assumed to react with site 2 in such a way that the C-6 group is free. The free groups of both 
molecules meet at site 3 and there react to form glucose-6-phosphate. If site 3 is already occupied by glucose-6-phosphate, reaction cannot occur. ATP at site 1 is converted to ADP as a result of the reaction and on the basis of the scheme one might expect a competitive inhibition of brain hexokinase by $A D P$, reversible by increasing concentrations of ATP. This point can only be tested with preparations of animal hexokinase free of myokinase. It is hoped to investigate this problem in the future.

\section{SUMMARY}

1. The reactions occurring in aqueous rat-brain extracts during the phosphorylation of glucose by adenosinetriphosphate (ATP) and the properties of rat-brain hexokinase have been investigated.

2. Estimation of the Michaelis constant yielded approximate values of $5 \times 10^{-5} \mathrm{M}$ for hexokinase and $7 \times 10^{-4} \mathrm{M}$ for phosphohexokinase. The affinity for ATP was the same for both enzymes. The Michaelis constant in this case was about $8 \times 10^{-4} \mathbf{M}$.

3. A study of the reaction products showed that glucose was quantitatively converted to hexosediphosphate and that glycolysis did not, under the conditions used, proceed beyond the triosephosphate stage. In the initial stages of the reaction some hexosemonophosphate may accumulate, especially when the enzyme is diluted.

4. The brain extracts used contained somewhat variable amounts of apyrase, myokinase and adenylic deaminase. The activity of myokinase was sufficient to prevent the accumulation of any but small amounts of adenosinediphosphate (ADP). When ADP was used as phosphate donor the reaction rate was about $30 \%$ slower than in the presence of ATP. But since ATP was always present in excess, even at the end of experiments, the activity of myokinase was never a limiting factor in the reaction. The ammonia formation from ATP, in absence of phosphate acceptors, was limited by the activity of apyrase rather than adenylic deaminase, while the ammonia formation from ADP was limited by the activity of adenylic deaminase rather than myokinase.

5. Brain hexokinase was strongly inhibited by hexosemonophosphates. Glucose-6-phosphate was found to be more inhibitory than fructose-6phosphate, while Robison ester has an effect intermediate between the two components. The results suggest that the inhibitory compound is glucose-6phosphate. The inhibition by hexosemonophosphates was non-competitive with respect either to glucose or ATP.

6. No summation of initial reaction rates of hexokinase and phosphohexokinase was observed when glucose and hexosemonophosphate were simultaneously added to brain extract, because hexokinase activity was inhibited in presence of hexosemonophosphate.

7. The addition of various substances known to have protective or activating effects on enzymes in general and on hexokinase in particular, alone or in combination, had no effect on the hexokinase activity of rat-brain extracts.

Our thanks are due to Dr R. Ström-Olsen, Physician Superintendent, for his interest and encouragement and to Dr Marjorie G. Macfarlane and Dr H. Waelsch for generous gifts of hexosephosphates.

\section{REFERENCES}

Berger, L., Slein, M. W., Colowick, S. P. \& Cori, C. F. (1946). J. gen. Physiol. 29, 379.

Colowick, S. P. \& Kalckar, H. M. (1943). J. biol. Chem. 148, 117.

Colowick, S.P.\& Price, W.H.(1945 a). J.biol. Chem.157,415. Colowick, S. P.\& Price, W.H. (1945 b). J.biol.Chem.159, 563.

Dounce, A. L., Rothstein, A., Beyer, G. T., Meier, R. \& Freer, R. M. (1948). J. biol. Chem. 174, 361.

Ebersole, E. R., Guttentag, C. \& Wilson, P. W. (1944); Arch. Biochem. 8, 399.

Fiske, C. H. \& Subbarow, Y. (1925). J. biol. Chem. 66, 375. Folin, O. \& Ciocalteu, V. (1927). J. biol. Chem. 73, 627.

Harpur, R. P. \& Quastel, J.H. (1949). Nature, Lond., 164, 693.

Lardy, H. A. \& Fischer, H. O. L. (1946). J. biol. Chem. 164, 513.

LePage, G. A. (1947). J. biol. Chem. 168, 623.

Lohmann, K. (1928). Biochem. Z. 203, 172.

Lohmann, K. (1932). Biochem. Z. 254, 381.

MoIlwain, H. \& Rodnight, R. (1949). Biochem. J. 44, 470.

Macleod, M. \& Robison, R. (1929). Biochem. J. $23,517$.

Martin, J. B. \& Doty, D. M. (1949). Anal. Chem. 21, 965.

Meyerhof, O. \& Geliazkowa, N. (1947). Arch. Biochem. 12, 405.
Meyerhof, O. \& Junowicz-Kocholaty, R. (1942). J. biol. Chem. 149, 61.

Meyerhof, O. \& Kiessling, W. (1933). Biochem. Z. 267, 313. Meyerhof, O., Ohlmeyer, P. \& Möhle, W. (1938). Biochem. Z. $297,113$.

Meyerhof, O.\& Randall, L. O. (1948). Arch. Biochem. 17, 171. Meyerhof, O. \& Wilson, J. R. (1948). Arch. Biochem.17, 153. Nelson, N. (1944). J. biol. Chem. 158, 375.

Neuberg, C., Lustig, H. \& Rothenberg, M. A. (1943). Arch. Biochem. 8, 33.

Parnas, J. K. \& Heller, J. (1924). Biochem. Z. 152, 1.

Potter, V.R.\& Elvehjem, C.A. (1936). J.biol.Chem.114, 495.

Roe, J. H. (1934). J. biol. Chem. 107, 15.

Taylor, J. F., Green, A. A. \& Cori, G. T. (1948). J. biol. Chem. 173, 591.

Weil-Malherbe, H. (1950). J. ment. Sci. 96, 226.

Weil-Malherbe, H. \& Bone, A. D. (1951 a). Biochem. J. 49, 348.

Weil-Malherbe, H. \& Bone, A. D. (1951 b). Biochem. J. 49, 355.

Weil-Malherbe, H. \& Green, R. H. (1951). Biochem. J. 49, 286.

Wiebelhaus, V. D. \& Lardy, H. A. (1949). Arch. Biochem. 21, 321. 